\title{
Model Pembelajaran Tutor Sebaya Pada Materi Sistem Peredaran Darah Manusia
}

\author{
Golda Nora Situmorang ${ }^{1)}$ g.n.situmorang@ gmail.com \\ Basa T. Rumahorbo ${ }^{2)}$ basarumahorbo3454@gmail.com \\ ${ }^{1}$ SMP Negeri 7 Mimika \\ ${ }^{2}$ Program Studi Magister Pendidikan IPA Universitas Cenderawasih
}

\begin{abstract}
This study aims to determine the differences in models of peer tutors on learning outcomes in the material of the Human Circulatory System. The method used in this study was experimental guasi with a sample of 100 people divided into two classes namely the control and experiment classes. The results of the study revealed that there were differences in learning outcomes between classes using the model of peer learning with conventional learning models this was evidenced by the value of Asymp. a large (2-tailed) value of 0,000 is generated from the T-test and the $n$-Gain average value uses peer tutors of 0.73 and a high category and those using the conventional learning model 0.34 , the medium category
\end{abstract}

Keywords: Peer Tutor, Human Circulatory System

\begin{abstract}
ABSTRAK
Penelitian ini bertujuan untuk mengetahui perbedaan model Tutor Sebaya terhadap hasil belajar pada materi Sistem Peredaran darah Manusia. Metode yang digunakan dalam penelitian ini adalah guasi eksperimental dengan sampel 100 orang yang dibagi menjadi dua kelas yaitu kelas kontrol dan eksperimen. Hasil penelitian mengungkapkan bahwa ada perbedaan hasil belajar antara kelas yang menggunakan model pembelajaran tutur sebaya dengan model pembelajaran konvensional hal ini dibuktikan dengan nilai Asymp. nilai besar (2-tailed) sebesar 0,000 dihasilkan dari uji-T dan nilai rata-rata nGain menggunakan tutor sebaya sebesar 0,73 dan kategori tinggi dan yang menggunakan model pembelajaran konvensional 0,34, kategori sedang
\end{abstract}

Kata kunci: Tutor Sebaya, Sistim Peredaran Darah Manusia

\section{PENDAHULUAN}

Depdiknas 2005 menyatakan pembelajaran IPA yang ditemui selama ini masih secara konvensional, seperti ekspositori atau ceramah. Proses ini hanya menekankan pada pencapaian tuntutan kurikulum dan penyampaian tekstual semata dari pada mengembangkan kemampuan belajar dan membangun individu. Kondisi seperti ini tidak akan menumbuh

kembangkan aspek kemampuan aktivitas peserta didik seperti yang diharapkan. Akibatnya nilai-nilai yang didapat tidak seperti yang diharapkan.

Berdasarkan observasi terhadap pelaksanaan pembelajaran IPA di kelas VIII SMP Negeri 7 Mimika tergambar adanya 
permasalahan pembelajaran, dimana dari proses pembelajaran selama ini ada sekitar $20 \%-60 \%$, hasil belajar biologinya nilai 50 di bawah Kriteria Ketuntasan Minimal $(\mathrm{KKM}=60)$ peserta didik mengalami kesulitan dalam belajar. Kesulitan belajar yang dialami peserta didik disebabkan oleh peserta didik kurang termotivasi dalam belajar dan cenderung pasif ketika proses belajar berlangsung. Rendahnya motivasi belajar peserta didik dipengaruhi oleh : 1) pembelajaran berpusat pada guru, 2) model pembelajaran yang kurang bervariasi, 3) menggunakan metode ceramah dan mencatat, 4) pengalaman belajar peserta didik kurang, 5)peserta didik cenderung pasif, 6) memiliki waktu belajar yang sedikit. Motivasi belajar peserta didik rendah mengakibatkan rendahnya hasil belajar.

Pada pembelajaran konvensional biasanya terdapat masalah dalam pembelajaran, maka dari itu dilakukan upaya untuk mengatasi permasalahan tersebut adalah dengan diterapkannya model pembelajaran tutor sebaya. Pembelajaran tutor sebaya menurut Azimatul. I dan Rusijono. 2010 merupakan metode pembelajaran yang terpusat pada peserta didik, dalam hal ini peserta didik belajar dari peserta didik lain yang memiliki status umur dan kematangan/harga diri yang tidak jauh berbeda, sehingga anak tidak merasa begitu terpaksa untuk menerima ide-ide dan sikap dari "gurunya" yang tidak lain adalah teman sebayanya itu sendiri.
Model pembelajaran tutor sebaya perlu diterapkan sebagai model pembelajaran yaitu tidak ada persaingan antarpeserta didik atau kelompok, karena mereka bekerja sama untuk menyelesaikan masalah dalam mengatasi cara berpikir yang berbeda. Dan alasan lain perlu diterapkannya metode ini karena dalam pelaksanaannya mampu menciptakan ruang psikologis yang nyaman bagi setiap anggota yang ada di dalamnya. Bantuan yang diberikan oleh teman-teman sebaya pada umumnya terasa lebih dekat dibandingkan dengan hubungan antara peserta didik dengan guru.

Peserta didik yang ditunjuk sebagai tutor ditugaskan membantu peserta didik lain yang mengalami kesulitan belajar berdasarkan petunjuk-petunjuk yang diberikan oleh guru. Selain itu kelebihan tutor sebaya yaitu peserta didik diajarkan untuk mandiri, dewasa dan punya rasa setia kawan yang tinggi. Artinya, peserta didik yang dianggap pintar bisa mengajari atau menjadi tutor temannya yang kurang pandai atau ketinggalan.

\section{METODE PENELITIAN}

Penelitian yang hendak dilakukan oleh peneliti ini menggunakan metode analisa desain quasi ekspriment (quasi experimental desing), dengan jenis desain non equivalent pre test - post test ditunjukan pada gambar 1.

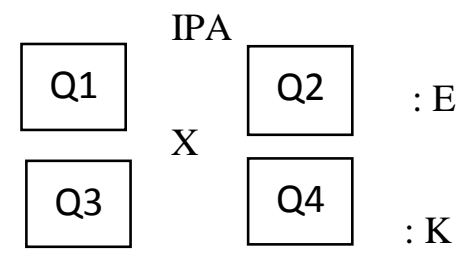


Gambar 1. Desain Penelitian

Q1 menyatakan pre test pada kelas VIII-C, Q2 menyatakan post test pada kelas VIII-C, Q3 menyatakan pre test pada kelas VIII-B, dan Q4 menyatakan post test pada kelas VIII-B.

Pre-test diberikan sebelum siswa mendapatkan perlakuan berupa penerapan model pembelajaran tutor sebaya pada kelas VIII-C dengan metode pembelajaran konvensional pada kelas VIII-B. Setelah mengadakan pre-test selanjutnya peneliti memberikan post-test.

Sampel dalam penelitian ini adalah peserta didik kelas VIII pada SMP Negeri 7 Mimika yang terdiri dari 5 kelas dengan jumlah 172 peserta didik. Sebaran peserta didik kelas VIII SMP Negeri 7 Mimika.

Dalam penelitian ini pengambilan sampel menggunakan teknik random sampling (sample acak) kelas dengan anggapan tingkat kemampuan semua individu adalah homogen. Pemilihan sampel penelitian dipilih secara acak berdasarkan atas kelas, bukan memilih individu-individu dalam populasi yang dijadikan kelas sampel. Proses acak dilakukan dan yang terpilih sebagai kelas sampel (kelas penelitian) adalah kelas VIII-Cdengan jumlah 34 peserta didik, sedangkan sebagai kelas kontrol adalah kelas VIII-B dengan jumlah 34 peserta didik.

Dalam penelitian ini pengambilan sampel dilakukan dengan teknik bertujuan atau purposive sample. Menurut Sugiyono (2012 : 124) "purposive sampling adalah teknik penentuan sampel dengan pertimbangan tertentu". Sedangkan menurut Suharsimi Arikunto (2010 : 183) "Sampel bertujuan (random sampling) dilakukan dengan cara mengambil subyek bukan didasarkan atas strata, random atau daerah tetapi didasarkan atas adanya tujuan tertentu".

Instrumen penelitian adalah suatu alat yang digunakan untuk mengukur fenomena alam maupun sosial yang diamati. Secara spesifik semua fenomena ini disebut variabel penelitian (Sugiyono, 2012:148).

Instrumen yang digunakan dalam penelitian ini terdiri atas dua, yaitu angket dan tes hasil belajar.

Hasil nilai tes awal dan tes akhir peserta didik dapat dilihat penguasaan terhadap mata pelajaran IPA sebelum dan setelah pembelajaran dengan tabel 1 .

Tabel 1 Tafsiran kemampuan Penguasaan

\begin{tabular}{|c|l|}
\hline Harga (\%) & $\begin{array}{c}\text { Kriteria } \\
\text { Kemampuan }\end{array}$ \\
\hline $81-100$ & Sangat baik \\
$61-80$ & Baik \\
$41-60$ & Cukup \\
$0-40$ & Kurang \\
\hline
\end{tabular}

Sumber : Arikunto (2005)

Motivasi belajar, diukur mengunakan instrumen berupa angket. Angket yang dibuat dalam skala Likert memiliki 4 jawaban yang sesuai dengan bobot pernyataan secara terurut yaitu Selalu $(\mathrm{SL})=4$, Sering $(\mathrm{SR})=3$, Jarang $(\mathrm{JR})=2$, dan Tidak Pernah $(\mathrm{TP})=1$. Skor akhir diperoleh dengan menghitung rata-rata, sehingga rentang skor berkisar antara 1-4 (Riduwan, 2008). 
Peningkatan hasil belajar peserta didik dapat diketahui dengan menggunakan analisis nilai Gain ternormalisasi. n-Gain dihitung pada kelas eksperimen dan kelas control ditunjukkan pada persamaan berikut

$$
n \text {-Gain }=\frac{\text { Pos test }- \text { pre test }}{\text { skor maks }- \text { pre test }}
$$

Dimana post-test adalah nilai masing-masing peserta didik dapat mengerjakan soal tes setelah materi diajarkan. Sedangkan pre-test adalah nilai masing-masing peserta didik dapat mengerjakan soal tes sebelum materi diajarkan. Dalam penelitian ini persamaan n-Gain digunakan untuk mengukur peningkatan penguasaan konsep siswa dengan kategori dapat dilihat pada tabel 2.

Tabel 2 Nilai Indeks n-Gain rata-rata

\begin{tabular}{|c|l|}
\hline Kategori & \multicolumn{1}{|c|}{ Nilai $\mathrm{n}$-Gain } \\
\hline Tinggi & $>0,7$ \\
\hline Sedang & $0,3 \geq$ N-Gain $\leq 0,7$ \\
\hline Rendah & $<0,3$ \\
\hline
\end{tabular}

Tabel 2 digunakan untuk melihat kategori dari penglihatan hasil belajar peserta didik.

\section{HASIL DAN PEMBAHASAN}

Berdasarkan tabel 3 dan gambar 2.

Tabel 3 n-Gain rata-rata Penguasaan konsep

\begin{tabular}{|c|c|c|c|c|}
\hline \multirow[t]{2}{*}{$\begin{array}{l}0,80 \\
0,60 \\
0,40 \\
0,20 \\
0,00\end{array}$} & \multicolumn{3}{|c|}{$0,30^{0,72} 0,33^{0,75} 0,3$} & 0,7 \\
\hline & K-1 & $\mathrm{K}-2$ & K-3 & s/d K-3 \\
\hline Tutor sebaya & 0,70 & 0,72 & 0,75 & 0,73 \\
\hline Konvensional & 0,39 & 0,30 & 0,33 & 0,34 \\
\hline Jumlah & 1,09 & 1,02 & 1,08 & 1,07 \\
\hline Rata-rata & 0,55 & 0,51 & 0,54 & 0,53 \\
\hline
\end{tabular}

Gambar 2 Hasil n-Gain rata-rata masingmasing Konsep

Hasil n-Gain rata-rata pada RPP I Materi Ajar Darah Manusia Uji n-Gain ratrata pada kelas eksperimen yang menggunakan metode tutor sebaya diperoleh nilai $\mathrm{n}$-Gain sebesar 0,70 sehingga penguasaan konsep peserta didik termasuk dalam kategori tinggi.

Hasil Uji n-Gain rata-rata pada RPP II Materi Ajar Alat Peredaran Darah dari hasil uji n-Gain pada kelas eksperimen yang menggunakan metode tutor sebaya diperoleh nilai $n$-Gain sebesar 0,72 sehingga penguasaan konsep siswa termasuk dalam kategori tinggi. Untuk kelas kontrol yang menggunakan metode ceramah dalam pembelajaran diperoleh nilai $\mathrm{n}$-Gain sebesar 0,30 maka penguasaan konsep termasuk dalam kategori sedang.

Hasil Uji n-Gain rata-rata pada RPP III Materi Ajar Peredaran Darah Pada Manusia hasil uji n-Gain rata-rata pada kelas eksperimen yang menggunakan metode tutor sebaya diperoleh nilai n-Gain sebesar 0,75 sehingga penguasaan konsep siswa termasuk dalam kategori tinggi. Untuk kelas kontrol yang menggunakan metode ceramah dalam pembelajaran diperoleh nilai n-Gain sebesar 0,33 maka penguasaan konsep termasuk dalam kategori sedang.

Hasil Uji n-Gain Rata-rata RPP I, II dan III uji n-Gain pada kelas eksperimen yang menggunakan metode tutor sebaya diperoleh nilai $\mathrm{n}$-Gain rata-rata sebesar 0,73 sehingga penguasaan konsep siswa termasuk 
dalam kategori tinggi. Untuk kelas kontrol yang menggunakan metode ceramah dalam pembelajaran diperoleh nilai $n-G a i n$ sebesar 0,34 maka penguasaan konsep termasuk dalam kategori sedang,

Untuk kelas kontrol yang menggunakan metode ceramah dalam pembelajaran diperoleh nilai n-Gain diperoleh level signifikansi sebesar $0,416>0,05$ yang berarti data berdistribusi normal, hasil uji normalitas Test Hasil Belajar Kelas Eksperimen RPP II diperoleh level signifikansi sebesar $0,317>0,05$ yang berarti data berdistribusi normal dan hasil uji normalitas test hasil belajar kelas eksperimen RPP III diperoleh level signifikansi sebesar $0,374>0,05$ yang berarti data berdistribusi normal. Sedangkan hasil uji normalitas Test Hasil Belajar Kelas Kontrol RPP I diperoleh level signifikansi sebesar 0,554>0,05 yang berarti data berdistribusi normal, hasil uji normalitas Test Hasil Belajar Kelas Kontrol RPP II diperoleh level signifikansi sebesar 0,187 > 0,05 yang berarti data berdistribusi normal dan hasil uji normalitas Test Hasil Belajar Kelas Kontrol RPP III diperoleh level signifikansi sebesar $0,127>0,05$ yang berarti data berdistribusi normal. Keseluruhan data sudah memenuhi syarat asumsi bahwa hipotesis dilakukan dengan menggunakan Uji t.

Uji Perbedaan Hasil Belajar Menggunakan Metode Tutor Sebaya dan Hasil Belajar Menggunakan Metode Konvensional sebagai berikut :

a. RPP I Materi Ajar Darah Manusia
Untuk menguji apakah hipotesis diterima atau ditolak, digunakan uji beda (uji t). Dari pengolahan data perhitungan uji beda untuk RPP I diperoleh $t_{\text {hitung }}$ sebesar 0,575 dan $t_{\text {tabel }}$ sebesar 0,308. Jika dibandingkan $t_{\text {tabel }}$ dengan ketentuan $\alpha=$ 0,05 dan $\mathrm{dk}=31$ ternyata $t_{\text {hitung }}>t_{\text {tabel }}$ atau 0,575 $>0,308$, maka $H_{a}$ pada hipotesis I diterima. Ini berarti bahwa terdapat perbedaan hasil belajar antara kelompok siswa yang mendapatkan perlakuan (treatment) dan kelompok siswa yang tidak mendapatkan perlakuan (treatment).

b. RPP 2 Materi Ajar Alat Peredaran Darah Manusia

Untuk menguji apakah hipotesis diterima atau ditolak, digunakan uji beda (uji t). Dari pengolahan data perhitungan uji beda untuk RPP II diperoleh $t_{\text {hitung }}$ sebesar 1,252 dan $t_{\text {tabel }}$ sebesar 0,426. Jika dibandingkan $t_{\text {tabel }}$ dengan ketentuan $\alpha=$ 0,05 dan $\mathrm{dk}=31$ ternyata $t_{\text {hitung }}>t_{\text {tabel }}$ atau $1,252>0,426$, maka $H_{a}$ pada hipotesis I diterima. Ini berarti bahwa terdapat perbedaan hasil belajar antara kelompok siswa yang mendapatkan perlakuan (treatment) dan kelompok siswa yang tidak mendapatkan perlakuan (treatment).

c. RPP 3 Materi Ajar Peredaran Darah

Untuk menguji apakah hipotesis diterima atau ditolak, digunakan uji beda (uji t). Pengolahan data perhitungan uji beda untuk RPP III diperoleh $t_{\text {hitung }}$ sebesar 2,530 dan $t_{\text {tabel }}$ sebesar 0,422 . Jika dibandingkan $t_{\text {tabel }}$ dengan ketentuan $\alpha=$ 0,05 dan $\mathrm{dk}=31$ ternyata $t_{\text {hitung }}>t_{\text {tabel }}$ atau 2,530 $>0,422$, maka $H_{a}$ pada hipotesis 
I diterima. Ini berarti bahwa terdapat perbedaan hasil belajar antara kelompok siswa yang mendapatkan perlakuan (treatment) dan kelompok siswa yang tidak mendapatkan perlakuan (treatment).

Pengamatan RPP I pada materi Darah Manusia bahwa aktifitas peserta didik pada kelas eksperimen dalam belajar kelompok belum terbiasa. Hal ini nampak dari hasil belajar peserta didik yang masih perlu lebih ditingkatkan lagi. Meskipun demikian, terdapat perbedaan nilai $\mathrm{n}$-Gain antara kelas yang mendapat pembelajaran Tutor Sebaya dengan kelas yang mendapatkan pembelajaran konvensional, n-Gain pada kelas eksperimen masih lebih tinggi jika dibandingkan n-Gain pada kelas kontrol. Jelas terlihat bahwa konsep materi Darah Manusia lebih mudah dipahami menggunakan model pembelajaran Tutor Sebaya karena dalam pembelajaran Tutor Sebaya peserta didik termotivasi untuk belajar dengan bantuan "gurunya" yang tidak lain adalah teman sebayanya itu sendiri sehingga materi lebih mudah dipahami. Sedangkan kelas kontrol menggunakan metode konvensional, n-Gain lebih rendah karena peserta didik hanya berdiskusi, sehingga sebagian peserta didik tidak ikut terlibat secara aktif. Hal ini menyebabkan pamahaman materi Darah Manusia tidak mudah dipahami peserta didik.

a. Hasil n-Gain rata-rata pada RPP II Materi Ajar Alat Peredaran Darah Manusia.
Hasil uji n-Gain pada RPP II pada materi Alat Peredaran Darah pada kelas eksperimen diperoleh nilai ratarata $\mathrm{n}$-Gain sebesar 0,72 sehingga penguasaan konsep termasuk dalam kategori tinggi, pada kelas kontrol diperoleh n-Gain sebesar 0,30 maka penguasaan konsep termasuk kategori sedang.

Pengolahan data uji beda (uji t) diperoleh hasil Asym Sig $=0,268>$ 0,05, maka $\mathrm{H}_{\mathrm{a}}$ pada hipotesis II diterima. Ini berarti bahwa terdapat perbedaan hasil belajar antara kelompok peserta didik yang diterapkan model pembelajaran masalah dengan peserta didik yang mendapat penerapan model pembelajaran konvensional.

Dalam penerapan model pembelajaran Tutor Sebaya, setelah peserta didik mendapat bantuan dari Tutor, peserta didik dituntut untuk mampu mengerjakan soal secara mandiri seperti yang sudah diberikan contoh oleh Tutor dan mengerjakan soal yang sudah dibuat, bahkan sekali waktu peserta didik diminta untuk menukar soal yang sudah dibuat dengan peserta didik yang lain. Sehingga seluruh peserta didik harus aktif dan termotivasi untuk dapat mencapai tujuan kompetensi yang ingn dicapai, sehingga diharapkan peserta didik memperoleh hasil belajar rata-rata diatas KKM (>60).

b. Hasil n-Gain pada RPP III Materi Ajar Peredaran Darah Manusia. 
n-Gain rata-rata RPP III pada kelas eksperimen diperoleh rata-rata nGain rata-rata sebesar 0,75 sehingga penguasaan konsep peserta didik termasuk dalam kategori tinggi. Untuk kelas kontrol yang menggunakan model pembelajaran ceramah memperoleh nilai $\mathrm{n}$-Gain sebesar 0,33 , maka penguasaan konsep termasuk dalam kategori sedang.

Hasil uji beda ( $U j i$ t) diperoleh hasil Asym Sig $=0,117>0,05$ berarti Ha pada hipotesis II diterima. Ini berarti bahwa terdapat perbedaan hasil belajar antara kelompok peserta didik yang mendapat perlakuan (treatment) penerapan model pembelajaran pengajuan masalah dan kelompok peserta didik yang diterapkan model pembelajaran konvensional.

Berdasarkan hasil $\mathrm{n}$-Gain rata-rata dan Uji $\mathrm{t}$ menunjukkan bahwa penerapan pembelajaran Tutor Sebaya yang telah terlaksana cocok untuk diterapkan untuk materi Peredaran Darah Manusia, peserta didik sudah mulai terbiasa dengan model pembelajaran Tutor Sebaya, terlihat dari semakin banyak peserta didik yang mengalami peningkatan hasil belajar dan motivasi yang semakin kuat. Peserta didik yang tuntas yakni 31 orang dari 31 peserta didik yang ada dikelas VIIIC, ini berarti ketuntasan $100 \%$ pada materi Peredaran Darah Manusia. Hal ini terjadi karena berdasarkan fakta pada belajar mengajar peserta didik sangat antusias dan semangat dalam mengikuti proses pembelajaran saat diminta untuk mengerjakan soal-soal secara mandiri setelah mendapat bantuan dari tutor sehingga dapat dapat mengikuti kegiatan pembelajaran dengan baik.

Penerapan model pembelajaran Tutor Sebaya tingkat pemahaman peserta didik terhadap materi pelajaran Peredaran Darah Manusia secara keseluruhan juga mengalami peningkatan.

Berdasarkan data hasil penelitian , secara keseluruhan ada peningkatan hasil belajar antara kelas yang diterapkan model pembelajaran Tutor Sebaya dengan yang hanya menggunakan model pembelajaran konvensional. Menurut Tiurlina Siregar \& Apriana (2013) bahwa perbedaan penggunaan model dalam pembelajaran dapat meningkatkan hasil belajar. Untuk meningkatkan hasil belajar peserta didik diperlukan motivasi yang kuat dari dalam diri peserta didik itu sendiri. Menurut Budi Pangerti (2015) bahwa model tutor sebaya dapat meningkatkan minat dan hasil belajar.

\section{SIMPULAN DAN SARAN SIMPULAN}

Ada perbedaan hasil belajar pada materi Sistem Peredaran Darah Manusia peserta didik kelas VIII di SMP Negeri 7 Mimika yang diterapkan model pembelajaran tutor sebaya dengan metode konvensional yaitu $n$-Gain rata-rata secara keseluruhan pada kelas eksperimen sebesar 0,73 berkategori tinggi dan kelas yang menggunakan model pembelajaran konvensional sebesar 0,34 berkategori sedang. 
71 | Jurnal Ilmu Pendidikan Indonesia 7 (2) : 64-71

SARAN

Dalam menerapkan pembelajaran dengan menggunakan pendekatan model Tutor Sebaya, seorang guru diharapkan dapat memilih peserta didik yang tepat sebagai tutor untuk membimbing teman lainnya yang mengalami kesulitan dalam memahami penjelasan dari gurunya.

DAFTAR PUSTAKA

Arikunto, suharsimi 2010. Prosedur Penelitian suatu pendekatan Praktik (Edisi Revisi). Jakarta : Rineka Cipta. Azimatul. I dan Rusijono. 2010. Pengaruh Penerapan Pembelajaran Tutor Sebaya Terhadap Hasil Belajar TIK. JurnalTeknologi Pendidikan. Vol.10, No. 2.

Budi pangerti, (2015).Pengaruh metode pembelajaran tutor sebaya terhadap motivasi belajar, minat belajar dan hasil belajar matematika kelas XI Ilmu alam MAN Model Sorong.
Jayapura: Jurnal Ilmu Pendidikan Indonesia,3(1) 18-27.Depdiknas. 2005. Ilmu Pengetahuan Alam. Jakarta : Direktorat Jenderal Pendidikan Dasar dan Menengah.

Riduwan, 2004, Metode dan Teknik Menyusun Tesis, Bandung : Alfabeta

Sugiyono, 2013. Metode Penelitian Pendidikan (Pendekatan Kuantitatif, Kualitatif, dan $R \& D$ ), Bandung : Alfabeta

Tiurlina Siregar dan Apriani Hujadjulu. (2013). Perbedaan hasil belajar menggunakan pembelajaran tipe Student Teams Achievement Division dengan tipe Think Pair Share pada materi faktor - faktor yang mempengaruhi laju reaksi di SMA Negeri 4 Jayapura: Jurnal Ilmu Pendidikan Indonesia, 1(2) 43-52 